\title{
Subdural haematoma and the malfunctioning shunt
}

\author{
A.H. MOUSSA A N D. K. S H A R M A \\ From the Departments of Neurological Surgery, Salford Royal Hospital, Salford, \\ and the Royal Manchester Children's Hospital, Manchester
}

SUMMARY Of 30 consecutive children with hydrocephalus treated by shunt implant, six developed subdural haematoma. Four of them presented with a malfunctioning shunt, and the diagnoses in all six cases were made by CT scan.

After the surgical treatment of a child with high pressure hydrocephalus, symptoms may recur because of blockage of the shunt system, and surgical revision of the shunt implant may be necessary. In some patients reactive subdural haematoma forms as the result of sudden shrinkage of the brain as the cerebrospinal fluid is drained away by the shunt implant. Subsequent symptoms caused by reactive subdural haematoma may cause diagnostic confusion and, if not detected, may lead to inappropriate treatment, usually an unnecessary revision of the shunt.

This communication describes six cases of subdural haematoma which occurred after operation in a consecutive series of 30 children with hydrocephalus treated by a ventriculoatrial or ventriculoperitoneal shunt. Four of these six children presented with symptoms suggesting blockage of the shunt implant, but the use of CT scan as a routine measure disclosed also the presence of asymptomatic subdural haematoma in two patients.

In a consecutive series of 175 hydrocephalic cases treated by insertion of a ventricular shunt, Illingworth (1970) recorded eight cases of subdural haematoma. Anderson (1952) described three cases of reactive subdural haematoma in a group of 24 infants treated surgically for hydrocephalus, and Davidoff and Feiring (1953) also reported three cases in a group of 85 chronic hydrocephalic children treated surgically.

\section{Summary of cases}

In the present group, whose details are summarised in the Table, the cause of hydrocephalus was defined in three patients, aqueduct stenosis, fourth ventricular exit atresia (Dandy Walker cyst), and

Address for reprint requests: Mr A. H. Moussa, Department of Neurological Surgery, Ain-Shams Faculty of Medicine, Cairo, Egypt. post-meningitic fourth ventricular obstruction respectively; in three cases the cause of communicating hydrocephalus was not evident. These diagnoses were confirmed before the shunt procedure by ventriculography with meglumine iocarmate in three cases and by CT scan alone in the other three cases. No preoperative evidence of subdural haematoma was seen in any of these patients. Five of these six patients underwent a Pudenz ventriculoatrial low pressure shunt, with an opening pressure of $20-50 \mathrm{~mm}$ of saline; the sixth case had an "Acuflo" low pressure ventriculoperitoneal shunt implanted.

Four of the patients subsequently presented with symptoms suggesting that the shunt was obstructed. In two (cases 2 and 3) no symptoms were present, but bilateral subdural haematomata were revealed by a postoperative CT scan.

Subdural haematoma was shown in all cases by CT scan obtained with an EMI head scanner, $160 \times 160$ matrix. The scan was repeated after intravenous injection of $30 \mathrm{ml}$ of sodium iothalamate $70 \%$. A haematoma as shown on CT scan took three different forms, that with a higher coefficient than the adjacent brain (35-45 EMI units), isodense (14-24 EMI units), and haematoma of lower density (4-14 EMI units), the appearance depending upon the age of the lesions, as mentioned by Scotti et al. (1977). The Figure illustrates a left subdural haematoma and ventricular catheter (case 4 ).

In one patient (case 6), an isodense lesion produced only ventricular displacement though subsequent angiography demonstrated the enormous subdural collection. In five cases, the CT scan alone was diagnostic. The extent of the lesion and its mass effect were well demonstrated on the CT scan. At the time of operation for hydrocephalus, four patients were under the age of six months. All four patients developed bilateral 
Table Details of patients studied

\begin{tabular}{|c|c|c|c|c|c|c|c|c|c|c|}
\hline $\begin{array}{l}\text { Case } \\
\text { number }\end{array}$ & $\begin{array}{l}\text { Hospital } \\
\text { number }\end{array}$ & Sex & Age & $\begin{array}{l}\text { Initial } \\
\text { investigation }\end{array}$ & $\begin{array}{l}\text { Initial } \\
\text { diagnosis }\end{array}$ & $\begin{array}{l}\text { Type of shunt } \\
\text { and pressure }\end{array}$ & $\begin{array}{l}\text { Interval from } \\
\text { last revision or } \\
\text { primary implant } \\
\text { to subdural } \\
\text { haematoma }\end{array}$ & $\begin{array}{l}\text { Presenting } \\
\text { symptoms }\end{array}$ & $\begin{array}{l}\text { Side of } \\
\text { subdural } \\
\text { haematoma }\end{array}$ & Treatment \\
\hline 1 & 96754 & $\mathbf{M}$ & 16 wk & CT scan & $\begin{array}{l}\text { Aqueduct } \\
\text { stenosis }\end{array}$ & $\begin{array}{l}\text { (R) Pudenz } \\
\text { VA 20-50 }\end{array}$ & $5 \mathrm{wk}$ & $\begin{array}{l}\text { Headache } \\
\text { vomiting } \\
3 \text { days }\end{array}$ & Bilateral & Observed \\
\hline 2 & 101733 & $\mathbf{F}$ & $18 \mathrm{wk}$ & CT scan & $\begin{array}{l}\text { Communicat- } \\
\text { ing hydro- } \\
\text { cephalus }\end{array}$ & $\begin{array}{l}\text { (R) Pudenz } \\
\text { VA 20-50 }\end{array}$ & $8 \mathrm{wk}$ & - & Bilateral & \\
\hline 3 & 96764 & $\mathbf{M}$ & $16 \mathrm{wk}$ & CT scan & $\begin{array}{l}\text { Communicat- } \\
\text { ing hydro- } \\
\text { cephalus }\end{array}$ & $\begin{array}{l}\text { (R) Pudenz } \\
\text { VA 20-50 }\end{array}$ & 9 wk & - & Bilateral & - \\
\hline 4 & 76486 & $\mathbf{M}$ & $1 \frac{1}{2} \mathrm{yr}$ & $\begin{array}{l}\text { Air-meglumine } \\
\text { iocarmate } \\
\text { ventriculograph }\end{array}$ & $\begin{array}{l}\text { Dandy-Walker } \\
\text { syndrome }\end{array}$ & $\begin{array}{l}\text { (R) Pudenz } \\
\text { VA 20-50 }\end{array}$ & $1 \frac{3}{4 r}$ & $\begin{array}{l}\text { Headache, } \\
\text { vomiting } \\
\text { anorexia } 1 \mathrm{wk}\end{array}$ & Left & $\begin{array}{l}\text { Burrhole } \\
\text { evacuation }\end{array}$ \\
\hline 5 & 95069 & $\mathbf{M}$ & 20 wk & $\begin{array}{l}\text { Air-meglumine } \\
\text { iocarmate } \\
\text { ventriculograph }\end{array}$ & $\begin{array}{l}\text { Post-meningitic } \\
\text { fourth ventricle } \\
\text { exit block }\end{array}$ & $\begin{array}{l}\text { (R) Acuflo } \\
\text { VP 20-50 }\end{array}$ & $8 \mathrm{wk}$ & $\begin{array}{l}\text { Vomiting and } \\
\text { convulsions }\end{array}$ & Bilateral & $\begin{array}{l}\text { Burrhole } \\
\text { evacuation }\end{array}$ \\
\hline 6 & 97136 & $\mathbf{M}$ & $4 \frac{8}{4 r}$ & $\begin{array}{l}\text { Air-meglumine } \\
\text { iocarmate } \\
\text { ventriculograph }\end{array}$ & $\begin{array}{l}\text { Communicat- } \\
\text { ing hydro- } \\
\text { cephalus }\end{array}$ & $\begin{array}{l}\text { (R) Pudenz } \\
\text { VA 20-50 }\end{array}$ & $2 \mathrm{yr}$ & $\begin{array}{l}\text { Headache, } \\
\text { vomiting, } \\
\text { malaise } 1 \text { wk }\end{array}$ & Left & $\begin{array}{l}\text { Burrhole } \\
\text { evacuation }\end{array}$ \\
\hline
\end{tabular}

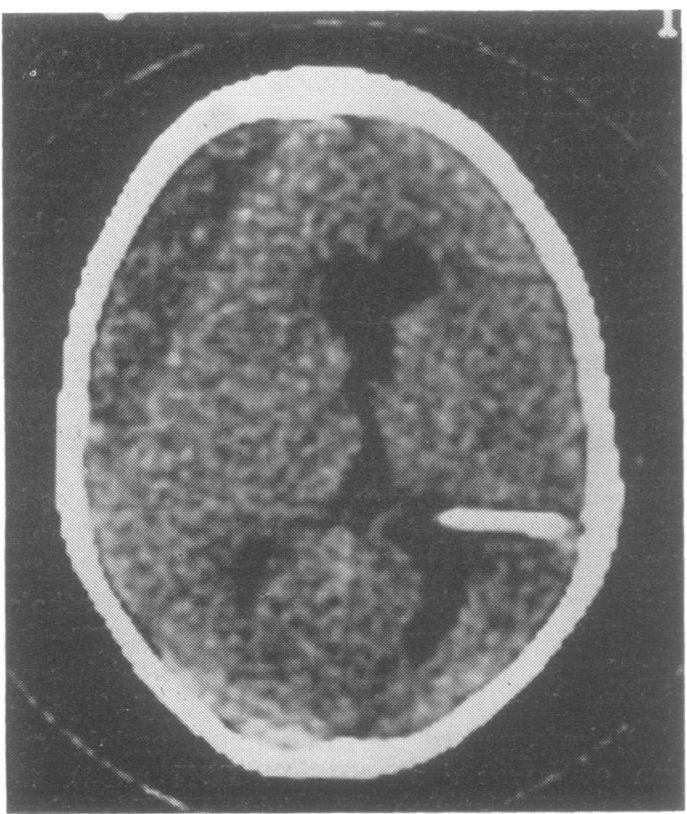

Figure CT scan showing left subdural haematoma and ventricular catheter (case 4).

subdural haematomata. The interval between the operation and the discovery of subdural haematoma in this age group varied between five and nine weeks. In three patients the operation was for primary implantation of a shunt, and for revision of the shunt in the fourth.

The other two patients (cases 2 and 6) were aged 18 months and 4 years 9 months at the time of operation which was for shunt revision and primary implant respectively. Both developed subdural haematomata contralateral to the operation site.

In three patients, haematomas were evacuated through burrholes. One case died on the first day after operation. The other two cases recovered $\frac{\Omega}{\overparen{D}}$ well. The remaining three cases did not require any treatment.

\section{Discussion}

Reactive subdural haematoma is thought to be the result of bleeding into the subdural space from the sudden reduction of intracranial pressure induced by CSF drainage. When the distended ventricles are drained and the intraventricular pressure is reduced, the brain tends to collapse, the subdural space widens, and disruptive traction is brought to bear upon the bridging veins. Skull enlargement, if present, exaggerates this effect, because of the great discrepancy in volume between the size of the brain and that of the cranial cavity. It appears that subdural haematoma may develop insidiously after operative decompression of the hydrocephalic brain, the enlarging haematoma easily acquiring room by occupying the space created through loss of cerebrospinal fluid, or by depressing the brain. The discovery of subdural haematoma in a patient with virtually no symptoms is of interest. It suggests that some sort of balance can be reached between the pressure in the subdural fluid and the pressure in the shunted ventricles.

In all these 30 patients, a low pressure release valve was inserted. This must be thought to be the most important factor contributing to the 
development of the subdural haematoma, but it is worth noting that Portnoy et al. (1973) found the antisyphon valve did not decrease the incidence of subdural haematoma, although it was effective in preventing marked lowering of intraventricular pressure when the patients were placed in the upright position.

Subdural haematoma can occur as a complication of a shunt procedure, and it should be considered in any patient who presents with malfunctioning shunt or who does not show the expected recovery after revision of a shunt. CT scan is a quick and easy way of detecting reactive subdural haematoma.

\section{References}

Anderson, F. H. (1952). Subdural hematoma, a complication of operation for hydrocephalus. Pediatrics, 10, 11-18.
Davidoff, L. M., and Feiring, E. H. (1953). Subdural hematoma occurring in surgically treated hydrocephalic children with a note on method of handling persistent accumulations. Journal of Neurosurgery, 10, 557-663.

Illingworth, R. D. (1970). Subdural haematoma after the treatment of chronic hydrocephalus by ventriculo-caval shunts. Journal of Neurology, Neurosurgery, and Psychiatry, 33, 95-99.

Portnoy, H. D., Schulte, R. R., Fox, J. L., Croissant, P. D., and Tripp, L. (1973). Anti-syphon and reversible occlusion valves for shunting in hydrocephalus and preventing post shunt subdural hematomas. Journal of Neurosurgery, 38, 729-738.

Scotti, G., Terbrugge, K., Melancon, D., and Belanger, G. (1977). Evaluation of the age of subdural hematomas by computerised tomography. Journal of Neurosurgery, 47, 311-315. 